\title{
O convívio acadêmico e a formação da nacionalidade brasileira
}

\author{
A. Almeida Júnior
}

Feitas tôdas as contas, apura-se com certo desencanto que foi má, durante o século passado, a atuação pròpriamente didática das velhas Academias oficiais brasileiras. Eram quatro: - a de São Paulo, a de Pernambuco, a do Rio e a da Bahia. Funcionando as quatro em instalações deficientes; mantendo suas cátedras, de regra, mal providas; primando a maior parte de seus lentes pelo desamor à renovação científica, pelo desinterêsse em relação aos alunos e pela falta de assiduidade; procuradas por moços geralmente sem preparo, sem gôsto pelas matérias lecionadas, indóceis à disciplina; e subordinadas as suas bancas julgadoras à asfixiante pressão do meio social, - não há do que nos surpreendermos por aquela consequência. Foram as Academias pouco eficientes, de fato, em sua tarefa de formar juristas ou médicos (1).

Nem por isso, entretanto, temos o direito de fazer côro com os que, durante a própria Monarquia, consideravam perdido o dinheiro que o Brasil estava gastando em seu ensino superior. Se em nenhum tempo nem em

(1) A. Almeida Jinion - Antes do Ensino Livere, Rev. Bras. de Est. Pedagógicos, Rio, Vol. XV, n. 41. Sinva-nos de consôlo o fato de que, embora menos defeituosos que os do Brasil, eram assim mesmo muito ruins, no século passado, os cursos universitários de formação profissional de quase iôda a Europa e dos Estados Unidos. 
nenhum lugar as funções das escolas universitárias se exgotam com lecionar e tomar exames, que dizer-se, então, de faculdades que se instalam num país novo, imenso, de população rarefeita e heterogênea, como era o Brasil, e que de súbito se vê independente? Outras tarefas, não previstas na lei, estavam reservadas às Academias imperiais; tarefas de importante significação para os destinos do país, e das quais aquelas casas de ensino se desincumbiram com exito integral. E mesmo, segundo nos parece, da intuição imprecisa que disso se tem, aliada ao saudosismo inerente à psicologia humana, que nasce hoje o elogio mais ou menos hipertrófico que lhes endereçamos. Todos as queremos como que por instinto; mas, ao racionalizarmos o nosso amor, enquanto lhes atribuimos excelências que em verdade não possuiram, deixamos no olvido as suas verdadeiras virtudes.

Procuremos, pois, acertar os relógios da nossa admiração e entender nos devidos termos o papel efetivamente representado pelas velhas Academias.

Em primeiro lugar (e diga-se isto como atenuação à censura introdutória), deram elas, aos jovens que por j́ndole mais se afeiçoaram ao direito e à medicina, as primeiras diretrizes; o que permitiu, posteriormente, que os ensaios e erros da vida prática e o autodidatismo fizessem de alguns dêles profissionais de elevada competência. Se outras houvessem sido as condições materiais e didáticas das escolas, é licito supor que o mesmo esfôrço os teria conduzido a posições culturais de muito maior destaque até no canário internacional. Ainda assim, o fato é que das modestas faculdades jurídicas e médicas da Monarquia, proveio o elemento humano com que o país mobilizou os primeiros quadros dêsses dois exércitos indispensáveis a qualquer nação civilisada: - o que defende a saude da população e o que assegura a distribuição da justiça.

Concorreram as Academias, em segundo Iugar, numa época em que começavam a orientar-se os rumos. 
da nossa evolução social, - para a rápida debilitação dos preconceitos de desigualdade por motivo de família, diferença racial ou fortuna. Através delas, muitos moços de ascendência ignorada, ou de pele escura, ou sem posses, - desde que dotados de inteligência e capazes de redobrado empenho, - conseguiram alterar-se na siciedade e assumir, até, postos de liderança na vida administrativa ou cultural do país (2). As quatro instituições de ensino fucionaram, pois (para usarmos a expressão de Arsène Dumont), como "pavio de lamparina", ao longo do qual, por capilaridade, numerosos espáritos robustos puderam vencer as barreiras opiostas à sua ascensão. Isto fazendo, ou seja proporcionando à jovem sociedade novos critérios de valor e novos títulos de hierarquia, vieram cooperar democnàticamente na tarefa que o mundo moderno atribui aos institutos escolares, $\ldots$ de aparelhos de redistribuição social.

\section{O CONVIVIO ACADEMLCO NO BRASIL IMPERLAL}

Função igualmente oportuna, e mais ampla do que qualquer das anteriores (porque, além de favorecê-las, acarretou novos benefícios), foi a de oferecer aos moços inteligentes de então, esparsos pelo território nacional, o ensejo de se reunirem e de conviverem livremente uns com os outros. Essa concentração da juventude brasileira em quatro das mais povoadas capitais do Império em formação, teve, como se verá, as mais valiosas consequências.

(2) Pimenta Bueno - uma criança exposta, - chega a Ministro do Supremo Tribunal, presidente de provincia, senaıor, ministro de Estado, conselheiro de Estado, diplomata. João Crispiniano Soares, - filho natural, — vem a ser professor de direito romano, deputado, várias vezes presidente de provincia. Rubino de Oliveira, - pobre e de côr escura - de seleiro o jócquei, que foi na juventude, subiu a professor do Curso Juridico. Muitos outros exemplos poderiam ser citados. 
O convívio acadêmico, fora das aulas, sempre caracterizou a vida universitária europeia, desde a Idade Média. Reuniam-se os moços das Universidades em esquadras agressivas, em bandos foliões, em agrupamentos de estudo, em sociedades secretas. Juntavam-se principalmente nas suas repúblicas ou nos colégios residenciais. Estes últimos, típicos de Oxford e Cambridge, atravessaram mais tarde o Atlântico para se expandirem nas lindas Cidades Universitárias do Estados Unidos.

No Brasil do século passado, que adotou para os alunos de gráu superior a vida residencial em repúblicas, as sedes das quatro faculdades, em virtude da proporção relativamente alta de estudantes que nelas se aglomeravam, - e sobretudo por causa da conduta turbulenta e invasora dos moços, - mereceriam considerar-se Cidades Universitárias "par droit de conquête". São Paulo e Olinda realmente o foram.

Sôbre o planalto paulista floresceram repúblicas acadêmicas, que, imitando a distribuição por "nações" das primeiras Universidades da Europa, tomavam algumas vezes nomes correspondentes às prov'ncias de seus participantes. Mas os moços, nem por isso, nem por se renderem de algum modo às afinidades regionais, deixavam de participar ativamente na vida coletiva (3). Confraternizavam tanto nas repúblicas, - sempre abertas a todos, - como também nos teatros, nas associações, nas lojas maçônicas, onde quer que se discutisse ou que houvesse diversões: "era natural (escreve Spencer Vampré) que a Academia. com cêrca de duzentos rapazes, predominasse na cidade"

(3) "Muito capazes de se unir entre si, os mineiros tendiam por isto mesmo para um relativo isolamemto no meio dos outros. Isolamento que não tinha nada de hostil..." tanto que "a natural tendência à composição levava os estudantes mineiros à prática associativa", tendo êles cooperado com os rapazes das outras províncias na fundação de várias sociedades. (A. Arinos de Melo Franco - Afrânio, estudante em São Paulo. Digesto Econômico, S. Paulo, janeiro, 1952). 
(4). E, sobrelevando em importância como ponto de concentração quotidiana, alí estava ainda o claustro conventual do largo de São Francisco, - as famosas "Arcadas".

Em Pernambuco, a cidade de Duarte Coelho, por seu lado, parecia predestinada a converter-se com o tempo num grande "campus" universitário. E' o que Liberato Barroso deve ter sonhado. "Tudo na antiga Cidade (disse êle, já quando o seu sonho se dissipara) tudo falava ao entendimento e à imaginação do jovem cultor das letras. As heróicas tradições nacionais, os seus antigos e magestosos templos (...), os monumentos do gênio holandês (. .), os seus claustros com as suas ricas e abandonadas bibliotecas (...), o silêncio de sua solidão, cheio das mais sublimes inspirações poéticas (...), os vastos horizontes que se descortinam de suas eminências (...), tudo finalmente faz da antiga sede da Academia de Olinda a morada das inspirações, da meditação e do estudo" (5). $\mathrm{E}$ assim foi, de certa maneira, até 1854. A vida dos mocos alí (depõe Carvalho Moreira, estudante de 1834 a 1839), "era completamente escolástica. Concorria para isso a isolação da velha cidade, limitada em número de habitantes, sem recursos nem distracõos. Conheciamos, por assim dizer, todos os moradores, a começar do chantre da Sé. Socialmente, as idéias, os hábitos, o espírito de corporação formavam para os acadêmicos uma existência à parte. Dominávamos completamente a cidade..." (6). Mas em 1845, transferido o Curso Jurídico para o Recife, a grei juvenil começou a diluir-se no borborinho da cidade comum: "incorporaram-se os estudantes na sociedade (notou Clovis Bevilaqua), com desvantagem para o desenvolvimento intelectual." $\quad €$ verdade que nem

(4) Spencer VAMPrÉ - História da Academia de São Paulo, Livraria Acadêmica, São Paulo, 1924, Vol. I, pág. 383.

(5) J. Liberato Barroso - A Instrução Pública no Brasil, Garnier, Rio, 1867, págs. 81-82.

(6) Apud Clovis Bevilaqua - História da Faculdade de Direito do Recife, Livraria Alves, Rio, 1927, Vol. I, pág. 440. 
assim se extinguio o convivio acadêmico. Sómente a partir de 1879, após inaugurada a frequência livre, é que "a prouco e pouco foram escasseando as repúblicas de estudantes" e esmorecendo, assim, "o contacto, a convivência, tão útil pela penetração e difusão das idéias" (7).

Quanto às duas escolas médicas do século passado, as crônicas que nos chegaram às mãos dizem muito pouco a respeito da atuação espontânea, de caráter social ou cultural, dos estudantes. Falam mais em greves ou reações agressivas contra professôres. A Bahia, entretanto, por suas estimulantes belezas naturais, por suas condições de cidade relativamente pequena e pela expansividade de sua gente, há-de ter oferecido um ambiente ideal para as expressôes do espírito acadêmico. Lá encontramos em 1923, como relíquia de antiga república de estudantes paulistas, uma mesa em que cada um esculpira a canivete o seu próprio nome. Na Côrte, outros rumores ensurdeciam a voz dos futuros esculápios. Demais, talvez fossem menos vivos os pendores poéticos ou tribunícios dêstes moços, pois a própria escolha do curso médico deveria ter selecionado as mentalidades mais interessadas pelos estudos objetivos. Isto não impediu que os alunos do Rio e da Bahia comparticipassem ativamente, na vanguarda, dos grandes movimentos políticos ou sociais da vida brasileira (8).

Como escolas superiores, estiveram as quatro faculdades, por muito tempo, sem outra companhia, pois a Escola Politécnica do Rio só apareceu em 1874 e a de Minas, de Ouro Preto, em 1875. Eram as únicas no ter-

(7) Clovis Bevilaqua — Op. cit., pág. 446.

(8) Fernando Maigalhães - O Centenário da Faculdade de Medicind do Rio de Janeiro, Tip. A. P. Barthel, Rio, 1932, págs. $32,47,61,69,114,115$. O papel desempenhado por Lopes Trovão, acadêmico de Medicina, na propaganda republicana, é bem conhecido. 
ritório nacional; de sorte que a elas tinham de dirigir-se obrigatóriamente os moços que, por vontade própria ou desejo da família, decidiam elevar-se acima dos preparatórios. Em relação a muitos dêsses jovens a profissão pouco importava: ambicionavam o título de doutor e o anel de rubí ou de esmeralda, quando não simplesmente o ensejo de viver parte da mocidade numa das quatro mais florescentes capitais do palís. $O$ fato é que iam para a Côrte, para a Bahia, ou, preferentemente, para São Paulo e Pernambuco, cujas escolas jurídicas reclamavam de seus alunos trabalhos menos concretos, abrindo-lhes ao mesmo tempo, à indiferença vocacional, maior variedade de perspectivas. O regime de frequência obrigatória, vigorante até 1879 , fornecia no mínimo o pretexto para que deixassem o ambiente paroquial da cidade do interior, a rusticidade da fazenda ou do engenho; para que se alforriassem do pai e viessem, donos de si mesmos, residir na sede do curso. Pouco importa que muitos, iludindo a lei, o lente e o bedel, fưgissem sistemáticamente das aulas: restava-lhes sempre, como estímulo civilisado: de incomparável eficácia, o convívio dos moços entre si.

\section{O VALOR CULTURAL DO CONVIVIO ACADEMICO}

Em livro saido a lume em 1949, "Sir" Walter Moberly exalta o valor cultural do convívio acadêmico, dizendo: "Viver na residência universitária, e dessa forma misturar-se com outros jovens provenientes de regiões e de variados tipos de lar, com jovens de temperamentos, interêsses e objetos de estudo diferentes, - constitui um contínuo exercício de entendimento recíproco e de adaptação social." Para êle, não é tanto através das lições magistrais que Oxford e Cambridge têm exercido sua grande influência sôbre a formação da mentalidade da Inglaterra, e sim pela vida residencial em comum, peculiar àquelas instituições. E o universitário britânico recorda, a propósito, a atitude do Cardeal Newman, em face da hipó- 
tese de ter que optar entre o sistema de ensino sem lições, baseado apenas na convivência dos moços entre si, e o sistema que, impondo aulas e exames, impeça a convivência: "- Sem a menor hesitação (dizia o eminente prelado), prefiro o primeiro" (9).

Foi por volta de 1854 que Newman, então no reitorado da Universidade Católica de Dublin, visando acen-tuar o valor formativo dos contactos culturais juvenis, lançou êsse paradoxo. Três anos antes, em 1851, o nosso Zacarias de Goes e Vasconcelos afirmara da tribuna da Câmara:

"Os moços, só pelo fato de morarem juntos, e de estarem sempre em contacto, comunicam-se reciprocamente, pela conversação e questões em que costuman entrar, idéias que beberam de seus mestres e dos bons livros. "e, assim, "recìprocamente se instruem." Variantes do mesmo pensamento se repetem desde então, na voz dos mestres. pernambucanos ou de seus discípulos. Em Olinda (ec1mentou Aprígio Guimarães, bacharelado em 1851)," contraia-se um espírito de corporação, formavam-se os primeiros enlaces da mocidade, e bem assim os seus primeiros principios, e, com êles, recebiam-se as primeiras idéias da profissão a que cada qual se dedicava; enlaces, principios e idéias que têm grande influência em todo o decurso da vida" (10). Adelino Filho, Martins Junior eConstâncio Pontual, em 1889, integrando uma comissão de professôres que reclamam contra o "ensino livre" de Leôncio de Carvalho, escrevem: "A convivência supre a falta de estudos que todos notamos na maior parte dos moços que frequentam as nossas Academias" (11). Oito anos: mais tarde, em 1897, tratando do mesmo assunto e obser-

(9) "Sir" WALTER MOBERLy - The Crisis in the University, SCM Press Ltd, Londres, 1949, pág. 34. O Autor é piresi dente do "University Grants Committee".

(10) Phaelante DA CÂmara - Memória histórica de 1903. in Rev. Acadêmica do Recife, Ano XII.

(11) Revista Acadêmica do Recife, Ano $I I$. 
vando que a frequência livre dispersara a mocidade, Tito de Almeida registra: "O espírito de coleguismo e associação, a solidariedade entre os estudantes, são ainda em grande parte o fruto da frequência às aulas" (12). En 1903 é a vez de Phaelante da Câmara: "o simples tirocinio escolar (disse êle), a camaradagem intelectual dos alunos nos bancos acadêmicos, o contágio do meio (. ), dĩo. só por si, o verniz de bacharel com que os nossos discipulos se apresentam na vida pública" (13). Clovis Bevilaqua, ao lastimar o esmorecimento dos contactos entre os moços, resultante da Reforma de 1879 , recorda: "reunidos, palestrando, discutindo, os espíritos adquiriam amplitude e agilidade, e até os menos diligentes, por êsse meio, recebiam, ainda que numa fraca repercussão, as idéias dominantes no meio" (14) Antes dêle, em 1894, na Câmara Federal, já se fizera sentir a voz de um filho espiritual do Recife, o deputado Anísio de Abreu, que aludira aos "elos desta harmonia fraterna que se adquire na convivência quotidiana dos bancos escolares e que se constituia a fôrça, a beleza e a dignidade das corporações acadêmicas." E o eloquente representante do Piaúi adverte que essa convivência diária era, não apenas fonte de afeições, mas também de cultura: "Ali havia a luta da inteligência, e, nos torneios científicos e literários, na emulação despertada pela nobre ânsia do saber, o carater se disciplinava, o espírito enriquecia-se de conhecimentos.."

O valor dos contactos pessoais próximos e reiterados — dos "contactos primários" — é um dos truismos da Sociologia. No comércio de todos os dias, em plena liberdade, os moços inteligentes disciplinam as suas reações, - afinam as cordas da sua sensibilidade, alargam os seus horizontes culturais; o bom gôsto de uns corrige o pedan-

(12) Tito dos Passos de Almeida Rosas - Memória histórica de 1897, in Rev. Acadêmica do Recife, Ano VIr.

(13) Phaelante da CÂmara - Loc. cit.

(14) Clovis Bevilaqua - op. cit., Vol. I, pág. 446. 
tismo de outros, todos se desenvolvem, fazem-se homens, aprendem por experiência direta e intransferível a arte de viver em sociedade. Tão sómente por êsse primeiro banho lustral de civilização, a que submeteư os futuros líderes da comunidade nacional, já merecem as quatro Academias que lhes escrituremos um alto crédito de gratidão.

\section{ESTÍMULO E ORIENTAÇÃO}

Nas quatro antigas faculdades brasileiras - e especialmente nos dois cursos de direito, - o atrito de todos os dias entre os estudantes valeu mais, em conjunto, do que a lição dos mestres. Fora das aulas, e depois de satisfeitos os impulsos para a turbulência, que é que fazem, no século passado, os moços inteligentes das Academias? Uns se encontram nesta ou naquela república, para dizer versos, discutir, mostrar ensaios filosóficos; outros fazem política no pátio da escola, vão a escritórios em que possam redigir artigos de jornal; à noite recitam nos salões, representam no teatro, examinam em lojas maçồnicas os problemas nacionais. Tudo isto, está cláro, com as limitações inerentes ao meio, à idade de cada um e à sua incipiente cultura. Mas, cada palestra a que assistem abre-lhes novas perspectivas; a vontade de aparecer leva-os a investigar as suas possibilidades pessoais; as criticas os corrigem, os aplausos os incitam a produzir mais e melhor.

Neste sentido as velhas faculdades brasileiras desempenharam de algum modo, em relação à juventude da época (ainda que sem intenção nem sistema), o papel que, em nível inferior, a "escola compreensiva" dos Estados Unidos e as "classes de orientação" da Reforma Lange. vin, na França, estão desempenhando em favor dos estudantes secundários: - pôsto cada adolescente em face dos múltiplos tipos de atividade que a vida oferece, procura êle próprio, por tentativas, descobrir aquele que lhe é mais grato e mais condiz com as suas aptidões. 
Tanto em Olinda como no Recife, são as atividades. marginais que tomam a maior parte do dia do estudante. Através dêsses exercỉcios vão êles se revelando e se adextrando. Na primitiva sede acadêmica nordestina predominam os duelos políticos, o alinhamento partidário, e com êsse vinco espiritual definitivo dali sáem Nabuco de Araujo, Angelo Moniz da Silva Ferraz, Euzébio de Queiroz Matoso, Wanderley, Sinimbú, Zacarias... O estudante José de Alencar, "como de pouco se carecia para (...) obter aprovação plena", lê alfarrábios e prepara os seus romances (15). Mais tarde, no Recife, em 1866, dois astros de primeira grandeza se aproximam, - Castro Alves e Rui Barbosa, - numa sociedade abolicionista (16). Eram então ocupações intelectuais dos moços as revistas, os jornais, as associações literárias, os clubes políticos, a crítica, os versos. Ali (conta Afrânio Peixoto" "a vida agitada e sôlta da Academia, onde os moços de talento porfiavam por aparecer, e a indole generosa de Castro Alves (...), fizeram dêle um tribuno e um poeta" (17). E é ainda o ambiente juvenil do Recife que, a partir de 1864, desperta e estimula as poderosas fôrças mentais de Tobias Barreto, tanto para a poesia como para os estudos filosóficos.

$\mathrm{Na}$ capital paulista o fenômeno se repetiria. Escrevendo em "Ensaios Literários" e deleitando os colegas com o seu humorismo, Bernardo Guimarães se orienta para as produções que lhe darão a glória; Pedro Taques, Rangel Pestana, Ferreira Viana, Américo de Campos, Alberto Salles e Julio Mesquita, fundando jornais acadêmicos ou neles colaborando, exercitam a pena com que irão, depois, robustecer o jornalismo brasileiro; José Bonifácio alça os primeiros vôos para a poesia e a oratória, que o celebri-

(15) Clovis Bevilaqua - Op. cit., Vol. II, pág. 238.

(16) Idem - Op. cit., Vol. II, pág. 91.

(17) Afrânio PeIXoto - Introdução às Obras Completas de Castro Alves, Comp. Edit. Nacional, S. Paulo, 1938, Vol. I, pág. 13. 
zarão; Lafayette - futuro jurisconsulto e estadista, preside gravemente o "Ensaio Filosófico"; no jornalismo, nas associações acadêmicas e no trato quotidiano, Rodrigues Alves já se mostra o trabalhador consciencioso e seguro que, ao colar gráu em 1870 , receberá de João Mendes esta profética apreciação: "Caráter sisudo, inteligência cultivada, ideias sãs, são elementos que o sr. Rodrigues Alves porá a serviço da Pátria. "(18).

"Nas repúblicas (nota Homero Pires) Alvares Azevedo entre companheiros mais próximos pela semelhança dos temperamentos, conversava longamente sôbre literatura, à Iuz trêmula das velas, nas frias noites do inverno paulistano" (19). Vindo em 1868 para São Paulo, Rui Barbosa encontra atividades que despertam latências do seu gênio, e vibrações sonoras que tocam as cordas sensíveis do seu espírito, feito para ressoar no fragor das lutas sociais " das pu'gnas politicas. $E$ ' onde "primeiro se sente homem para o combate". Por isso, lembrando-se de certo do "Radical Paulistano", em que escrevera; da "Loja América", em que terçara armas com Antônio Carlos; do salão Joquim Elias, em que prègara o abolicionismo, dirá mais tarde: "O tirocínio escolar, nesta cidade, sempre se animou ardentemente do espírito de luta, de civilismo, de reação liberal.." Castro Alves, ao chegar a São Paulo em 1868, é recebido como um jovem deus e tem aqui as maiores consagrações de sua vida. De sua parte, é êle dotado de grande tendência associativa: "Nenhum estudante (escreve Xavier Marques) soube, como êle, estreitar, com vinculos de fraternidade, a câmaradagem acadêmica" (20). A Raul Pompeia, "que as repúblicas paulistas com-

(18) Gontijo de Carvalho - Ensaios biográficos, S. Paulo, 1951, págs. $326-332$.

(19) Homero Pires - Obras Completas de Alvares de Azevedo, Comp. Edit. Nacional, S. Paulo, i942, Vol. I, pág. XIX.

(20) Apud Spencer VAMpré - Op. cit., Vol. II, pág. 257. Do mesmo precioso trabalho são extraidas as referências a Rui Barbosa. 
preendiam" (refere Eloy Pontes), "os encontros quotidianos abriram-lhe o espírito; os entusiasmos, contagiando-lhe a inteligência, fermentaram-lhe os planos de trabalho" (21).

Em suma, menos nas salas de aula do que através das: atividades livres provocadas pelo convívio acadêmico, ia cada estudante atritando as várias facetas do seu espirito, a fim de ver de qual delas brotaria a centelha da imortandade.

\section{CONVIVIO ACADEMICO E PROGRESSO SOCIAL}

Mas isto não é tudo. Além da tarefa de receber a facho da cultura, cabe à mocidade a de fazê-lo progredir. a de romper para a frente contra a apatia e a estagnação. E de interêsse, por isso, que, tão logo alcancem certo gráu de maturidade, os adolescentes se afastem dos meios retrógrados em que porventura hajam crescido, e possam. assim, entrando a viver a sua própria vida, adiantar de alguns passos a linha avançada da civilização.

A família brasileira do século XIX raramente oferecia ambiente propício às renovações. A criança, no lar, fazia-se rapaz de cambulhada com os moleques do terreiro e as negrinhas da copa, deixando-se embevecer em futilidades e aprimorar-se em perversões. Se alguma coisa aprendia a sério — quando aprendia, - era o formalismo das chamadas boas maneiras. Ao apontar-lhe o buço, já devia ter demonstrado a sua masculinidade; já devia ter brigado, jogado; já devia ter chafurdado no lodo das aventuras da carne, pouco se lhe dando que o fizesse em detestáveis condições de higiene física e moral. Mesmo quando os costumes eram bons, escasseavam, nas relações intimas com os pais, dois ingredientes, - a ternura e a confiança, - tão úteis para o equilibrio emo-

(21) Eloy Pontes - A Vida Inquieta de Raul Pompeia, Livraria José Olympio, Rio, 1935, pág. 66 . 
cional da juventude. O que dominava o quadro psicológico da famỉlia era o autoritarismo do pai, o seu poder despótico a coibir no filho as mais tímidas expressões de personalidade, visto que o ideal consistia na formação estereotipada da geração nova pelos moldes da geração anterior, - a mesmice atravẻs dos séculos. Em colaboração com os propósitos do lar, estenuavam-se mestres particulares de incrível sadismo. Estava no auge, então, a doutrina pedagógica que atribui eficácia "formadora" a certas disciplinas, e o latim, nesse particular, era considerado milagroso. Havia ordem, portanto, de fazê-lo entrar na cabeça do menino, ainda que fôsse pelas rachas da palma da mão...

Vinha depois o colégio, inspirado nas mesmas concepções. "Nos antigos colégios (lembra Gilberto Freyre), se houve por um lado em alguns casos lassidão - fazendo-se vista grossa a excessos, turbulências e perversidades dos meninos - por outro lado abusou-se criminosamente da fraqueza infantil. Houve verdadeira volúpia em humilhar a criança, em dar bolo em menino" (22). Eu próprio, menino de oito anos ao findar o século, e que por circunstância especial escapei ao suplício do internato, guardo a recordação da forma pela qual, apesar de já iniciado no país um certo abrandamento pedagógico, os pais ainda perturbavam o sono dos filhos com a simples ameaça de mandá-los para o colégio. Um símbolo dos tempos era o temível "Caraça", de que Minas ainda hoje se orgulha. Ergueram-no os lazaristas no ano de 1821, entre "montes de basalto e de granito", a lembrar "barbacãs e seteiras de gigantesco castelo medieval". Férias, não havia; as aulas prosseguiam sem interrupção ano após ano, e o Colégio, "com a sua severidade" e a "energia férrea" dos seus reitores, "manteve no Brasil o espírito de tradição"; de sorte que "em pleno sertão, filhos

(22) Gilberto Freyre - Casa-Grande e Senzala, Maia \& Schmidt, Rio, la. ed., 1934, pág. 450. 
de uma nação incipiente debatiam teses propostas em velhas Universidades" (23).

Não nos admire que um viajante estrangeiro, que nos visitou nos começos do século XIX, tivesse observado. falta de alegria nos meninos; e, nos rapazes, falta de vivacidade. É que, segundo notou êle, "a educação da época parecia reduzir-se a esta função melancólica: des-truir nos pequenos tôda a espontaneidade" (24).

Haveria, pois, de ser vantajoso à saude mental do moço brasileiro de então, e estimulante ao exercício de suas fôrças latentes, - libertar-se do lar e das morrinhentas ideologia's paternas, esquecer a palmatória do mestre, fugir à rispidez do colégio, para vir, enfim, mergulhar nas prodigiosas águas do Recife, da Bahia, do Rio ou de São Paulo, que lhe apareciam, em sonho, como outras tantas Canaãs onde lhe seria permitido escolher o* seu próprio caminho, sentir-se de algum modo dono de: si mesmo, ouvindo poetas como Castro Alves e oradores. como Joaquim Nabuco ou Rui Barbosa, a apontar à ju-ventude os ideais dos novos tempos.

E' verdade que alguns, precocemente cristalizados, re-sistiriam à mudança do clima espiritual $\mathrm{e}$, como adverteClovis Bevilaqua, não se desprenderiam da influência de. suas famílias. De regra, entretanto, cortavam-se as amarras. Entrava o moço, de súbito, numa atmosfera nova, irreverente, iconoclasta, mas em todo caso ricamente oxigenada por estímulos culturais. Ao fim de poucos meses. estava outro, - era maçon, livre-pensador ou positivista, discursava pelo liberalismo, pelo abolicionismo, quando. não pelos princípios republicanos. Talvez nem sempre entendesse bem as doutrinas que professava; contudo, a sonoridade das formas permanecia, e, com elas, novas atitudes do espírito; e se o ímpeto juvenil posteriormente:

(23) GontiJo de Carvaliho - Op. cit., págs. 452-453.

(24) Gilberto Freyre - Op. cit., pág. 440. 
se moderasse, se o moço voltasse atrás, nunca mais o seria para a situação doméstica original.

Organizava-se assim, em cada Academia, a equipe vanguardeira da Nação; o corpo de pioneiros que dentro em pouco, nas Câmaras e nos Ministérios (com desprêso cada vez maior pelo figurino lusitano, em favor do francês, inglês ou estadunidense), iria impulsionar a progressão da política brasileira e do nosso regime social. Se o Brasil não se estagnou no marasmo caudilhista de alguns países latino-americanos; se a influência política da Igreja foi temperada pelas resistências do regalismo; se a ordem juridica da Nação se manteve estável através do Império, e se após o trauma da proclamação da República se preservaram os princípios do civilismo, isso se deve, em boa parte, aos focos de difusão cultural instituidos graças ao livre convivio dos estudantes nas Academias.

\section{CONVIVIO ACADEMICO E UNIDADE NAGIONAL}

Dêsse convivio, e o do intercambio que houve entre - Rio e a Bahia, como entre Pernambuco e São Paulo, e também da continuidade estabelecida piela tradição, resultou ainda formar-se, nas várias gerações de moços, um: patrimônio comum de idéias, sentimentos e atitudes, que muito contribuiu para a vinculação afetiva e intelectual dos que compunham as classes dirigentes do país. Matriculavam-se em cada uma das Academias moços vindos de todos os quadrantes do Brasil, - da cidade ou do campo, do povo ou da aristocracia. Reuni-los diariamente em livre camaradagem, foi, sem dúvida, cooperar para a sua assimilação sentimental e ideológica, e para que viessem a usar, de norte a sul, o mesmo vocabulário espiritual. Em relação aos filhos dos lugares distantes, afeitos a prosódias domésticas ou regionais, êsse comércio quotidiano, em que conversavam livremente, expondo-se à crítica zombeteira dos colegas, foi uma ótima escola 


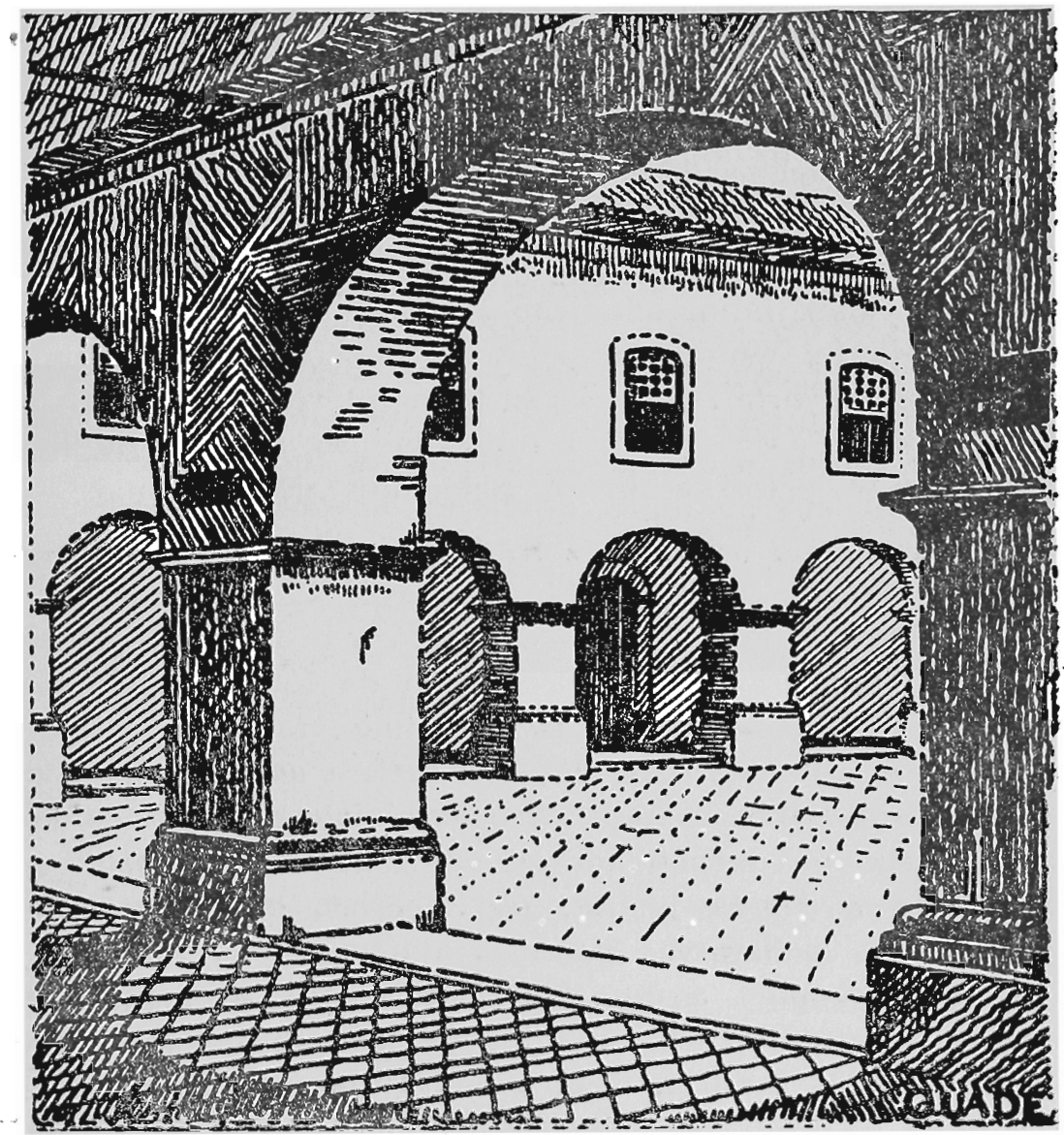

AS FAMOSAS ARCADAS

"Eu vejo, vivamente visto, o mosteiro daqueles tempos." (Ruy Barbosa) 
de homogeneização linguística. E escola também de homogeneização social. Phaelante da Câmara, escrevendo em 1903, assegura que, por obra da Academia do Recife, o próprio caráter pernambucano se modificou: "Os filhos de famílias poderosas, que viviam em luta acesa, os de sangue azul e os plebeus, os descendentes da fidalguia do Cabo e os representantes dos antigos "mascates", dalí sairam humanizados" (25).

Durante a vida acadêmica, a livre convivência faz nascer, entre os moços, amizades profundas, que os acoinpanham até à velhice. $\mathrm{E}$ não é só: ainda quando os cursos são frequentados em épocas diferentes, o simples fato de, no primeiro encontro, poderem dois homens recapitular juntos a mocidade vivida na mesma escola, de repetirem um ao outro o mesmo anedotário acadêmico e de evocarem as mesmas tradições, estabelece entre êles suave corrente de simpatia, que basta muitas vezes para facilitar entendimentos de outra forma dificeis. Anisio de Abreu, no mencionado discurso de 1894, falando dos torneios acadêmicos de sua juventude, relembra: "Geravam-se alí estas amizades que faziam ascender às altas posições da carreira política e administrativa, unidos, conhecendo-se e respeitando-se, aptos para mutuamente se fazerem a devida justiça, os Zacarias, os Nabucos, os Cotegipes, os Saraivas e tantos, tantos outros..."

Graças, pois, a um tipo de atividades não previstas nos regulamentos oficiais, olhadas com desconfiança pela maioria dos mestres, e quee, não raro, tinham o propósito de reformar as leis básicas do país, os pátios das velhas Academias $\mathrm{e}$ as repúblicas de estudantes influiram benéficamente no sentido de manter-se e revigorar-se a unidade brasileira.

Embora separadas uma das outras por consideráveis distâncias geográficas, as quatro faculdades imperiais conservaram-se vinculadas entre si pela semelhança psicoló-

(25) Phaelante da Câmara - Loc cit. 
gica de seus estudantes, e pelos comuns propósitos neles instilados através de reiterado intercâmbio. $O$ estilo de vida e os ideais as aproximavam, fazendo das quatro outros tantos núcleos sinérgicos de ordenação da vida nacional. Pareciam formar assim uma só entidade universitária, sob o grão mestrado do Ministro do Império; e não será inteiramente descabido dizer-se que naquele tempo, pelo que eram e pelo que realizaram, constituiram a verdadeira Universidade do Brasil.

\section{AS ARCADAS DiO LARGO DE SÃO FRANCISCCO}

Nesta questão de atividades de estudantes, a Faculdade de Direito de São Paulo merece uma referência especial. Efetivamente, como centro de convívio da mocidade acadêmica, o pátio central do Convento de São Francisco conquistou lugar de relêvo na vida brasileira.

A topografia da casa conventual - em pileno coração da cidade; a situação privilegiada do claustro, tornando-o de facílimo acesso aos estudantes; sua configuração, sua amplitude, a dignidade singela de suas linhas arquitetônicas, - tudo concorreu para acomodá-lo desde o início à elevada missão que lhe estava destinada. Eram os "Gerais", assim chamados por sua função, à moda do Coimbra, e a êles se refere em versos despretenciosos um estudante de 1830:

Depois ide mal amassada
A desfrutável lição,
Com uns cadernos na mão
Vamos aos Gerais (26).

Pelo correr do tempo, a contemplação insistente do recinto vai apagando a reminiscência coimbrã; os "Gerais" passam a ser as "Arcadas", e é sob êste rótulo, consagrado pela retórica juvenil, que o claustro franciscano do Curso I, 187.

(26) ANTonio de QueIRoga, in Spencer Vampré, Op. cit., 
Jurídico do Sul toma assento definitivo na história brasileira.

No São Paulo do século XIX, são as Arcadas a área predileta de contacto dos estudantes, antes e depois de cada aula. Visto que os lentes faltam muito, e que o quarto de hora entre uma e outra preleção tende sempre a espichar-se, e como é benévola a marcação da frequência, - pode-se afirmar de cada estudante, sem grande probabilidade de êrro, que o tempo que dedicou aos "Gerais" foi sensivelmente superior ao tempo de aulas. "Ia-se lá como quem vai para um clube" - declarou-me um antigo bacharel. Acresce que os professôres que, do alto das cátedras, lêem as suas postilas ou comentam os compêndios, ŝ̂̀ bem menos interessantes do que os jovens que, por sua conta e risco, prelecionam nos "Gerais" Êstes mestres improvisados chamam-se, conforme a época, Bernardo Guimarães, Alvares de Azevedo, Antonio Carlos, Josẻ Bonifácio, Castro Alves, Joaquim Nabuco, Rui Barbosa, José Maria da Silva Paranhos, Martinho de Campos, Raul Pompéia; - todo um rosário dourado de tribunos, poetas, jornalistas e politicos. Chegam a São Paulo no esplendor da mocidade, cintilam nas Arcadas durante alguns anos e saém deixando de si uma recordação luminosa. Sáem, mas à medida que seus nomes crescem na história nacional, fazem convergir de retôrno, para o Largo de São Francism, reflexos da luz que irradiam, e cuja claridade aumenta ainda mais o fulgor das tradições do velho claustro.

Vagas lembranças medievais, ajudadas pela fecundicade imaginativa da juventude, e também - por que não ،iizê-lo? - pelo instinto de conservação, fizeram das lages đo pátio uma espécie de chão sagrado. É o âmago do "território livre", e do seu contacto deve excluir-se tudo. quanto possa opor-se, pela fôrça bruta, às fôrças do espirito ou às naturais expansões da juventude. Em palavras mais concretas: - a Polícia aqui não entra! Em 1850, tempo de Alvares de Azevedo, como se esperassem tropelias por ocasião do trote aos calouros, o sub-delegado. 
gado da Sé oficia ao diretor da Academia, para dizer-lhe que mandará alguns soldados com a missão de manter a ordem. Ora, o diretor é Amaral Gurgel, bacherel da primeira fornada do Curso, liberal desde o tempo de estudante e que sente até na medula dos ossos a mística das Arcadas. Daŕ a sua resposta ao sub-delegado: "Acabo de receber o of ício de V. S., em data de hoje, em que. me comunica que chegou ao vosso (sic) conhecimento que se preparam caçoadas aos estudantes novatos, e para preveni-las V. S. pretende mandar alguns individuos do corpo policial, para manterem a ordem. Ao que tenho de responder que, dentro d'Os Gerais eu farei manter a ordem com os empregados da casa. "

As tradições se consolidam melhor quando há continuidade nos seus quadros materiais. Ainda neste ponto. a Academia de São Paulo foi feliz. As outras três escolas do Império, além de mal instaladas durante todo o sé culo, tiveram que mudar-se várias vezes. A de São Paulo, não: onde a Plantaram a $1 .^{\circ}$ de março de 1828 , data de sua aula inaugural, ali ficou. Esta permanência, jamais interrompida, confere só por si virtudes misteriosas ao velho claustro. O moço que aqui chega sabe que vai pisar o mesmo chão que pisaram quando jovens os: construtores do Brasil independente; sabe que êstes aspectos interiores da Academia são, em suas linhas gerais, os mesmos aspectos com que se familiarizaram dezenas de turmas acadêmicas, e que as placas de mármore de cada recanto gravam nomes de ano em ano mais veneráveis pela distância do tempo, mais brilhantes pelos feitos que recordam. Sente-se o recém-chegado, desde logo, prêso por fios misteriosos a essas tradições. $\mathrm{E}$ assim, no momento em que se integra, como um igual, na mesma comunidade a que pertenceram em sua juventude tantos. pró-homens da Nação, é natural que preste a si próprio um compromisso de fidelidade aos melhores ideais que êles aqui proclamaram. Desta forma ainda, sugerindo às. 
sucessivas gerações juvenís idênticos padrões de conduta cívica e moral, a vida acadêmica contribui com uma nova força para a unificação da nacionalidade.

\section{EM CONICLUSÃO}

Podemos afirmar, portanto, que, embora defeituosíssimas como escolas superiores destinadas a produzir profissionais, as velhas Academias do Império exerceram papel de considerável importância em nossa formação histórica. Reunindo boa parte dos moços brasileiros nos quatro centros urbanos mais populosos do país, elas lhes proporcionaram, através de contactos quotidianos e de atividades espontâneas, novos horizontes culturais, e bem assim ensejo a que suas fôrças latentes se despertassem e se encaminhassem no sentido das aptidões de cada um. Mais ainda: retirando êsses moços da influência conservadora dos lares, trazendo-os para a vida das repúblicas ou das associações juvenís, submetendo-os a vigorosos estímulos espirituais e a processos de socialização, puderam aquelas escolas, à revelia dos próprios mestres, formar as vanguardas políticas e doutrinárias do país, e, do mesmi) passo, fortalecer a unidade nacional. Isto basta para mostrar o grande valor que teve entre nós, no século passado, a livre convivência dos estudantes das Academias.

Será util, ainda, essa livre convivência, nos tempos atuais? Útil a cada moço, individualmente, e útil à coraunidade brasileira? Cremos que sim, não obstante haver o país sofrido, de lá para cá, profundas modificações demográficas, econômicas e sociais. O convívio acadêmico deve continuar a ser cultivado pelos moços e deve, igualmente, encontrar acolhida simpática da parte dos responsáveis pela educaçã̃o universitária. Que propósitos terá na atualidade êsse gênero de exercícios? Em que oportunidades se farão? E de que maneira? Mas isso é assunto que merece, só por si, um trabalho especial. 